\title{
SPIRITUALITAS AGAMA DAN ETOS KERJA MASYARAKAT DALAM PENANGGULANGAN KEMISKINAN NELAYAN DESA GRAJAGAN KECAMATAN PURWOHARJO KABUPATEN BANYUWANGI
}

\author{
Fina Nihayatul Khusna ${ }^{1}$, Pudjo Suharso ${ }^{1}$, Sukidin ${ }^{1}$ \\ ${ }^{1}$ Program Studi Pendidikan Ekonomi, Fakultas Keguruan dan Ilmu Pendidikan, Universitas Jember \\ e-mail: Finahnihayah31@gmail.com
}

\begin{abstract}
Abstrak
Kemiskinan sejauh ini masih dirasakan oleh masyarakat Indonesia begitupun pada masyarakat pesisir khususnya masyarakat nelayan Desa Grajagan Kecamatan Purwoharjo Kabupaten Banyuwangi. Mayoritas nelayan beragama Islam, ajaran agama Islam mengajarkan dan memerintahkan bahwa setiap manusia harus bekerja keras karena bekerja merupakan bentuk ibadah dan tanggung jawab dalam menafkahi keluarga. Namun, realitas yang terjadi pada masyarakat nelayan Desa Grajagan justru sebaliknya. Penelitian ini dilakukan untuk mendeskripsikan bagaimana spiritualitas agama masyarakat mendorong tumbuhnya etos kerja dalam penanggulangan kemiskinan nelayan Desa Grajagan Kecamatan Purwoharjo Kabupaten Banyuwangi. Teknik penentuan informan penelitian dalam penelitian ini menggunakan metode snowball. Metode penentuan lokasi penelitian menggunakan metode purposive area yaitu di Desa Grajagan Kecamatan Purwoharjo Kabupaten Banyuwangi. Metode pengumpulan data yang digunakan terdiri dari metode: wawancara mendalam, observasi dan dokumen. Analisis data yang digunakan yaitu dengan mereduksi data, menyajikan data, dan menyimpulkan data. Hipotesa yang dapat ditarik adalah meskipun nelayan memiliki etos kerja tinggi tetapi etika kerja yang dipahami kurang sesuai dengan apa yang diajarkan agama. Modal sosial yang tertanam dalam bentuk individu maupun kolektif sebagai strategi dalam penanggulangan kemiskinan nelayan.
\end{abstract}

Kata Kunci: Spiritualitas Agama, Etos Kerja, Penanggulangan Kemiskinan Nelayan.

\section{PENDAHULUAN}

Data statistik yang dirilis oleh Badan Pusat Statistika (BPS) terkait angka kemiskinan di Indonesia tahun 2017, memperlihatkan adanya penurunan angka kemiskinan. Adanya penurunan prosentase angka kemiskinan seyogyanya menjadi salah satu ciri keberhasilan pemerintah dalam mengatasi kemiskinan di Indonesia. Namun, realitas yang terjadi pada mayoritas masyarakat Indonesia justru kemiskinan begitupun yang terjadi pada masyarakat nelayan. Berdasarkan PP No 166 tahun 2014 pasal 1 ayat 1 menunjukkan bahwasanya dalam menanggulangi kemiskinan tidak hanya menjadi tanggung jawab pemerintah, melainkan masyarakat sendiri juga berperan dalam mengatasi masalah kemiskinannya. Salah satu cara yang dapat dilakukan masyarakat adalah dengan menumbuhkan dorongan semangat dalam bekerja.

Menurut Rokhimah, 2017:3 semangat bekerja dalam diri seseorang atau masyarakat dapat terbentuk karena adanya dorongan keyakinan dan motivasi. Mayoritas nelayan Desa Grajagan Kecamatan Purwoharjo Kabupaten Banyuwangi memeluk agama Islam. Islam memerintahkan manusia untuk bekerja atau mencari rezeki, bekerja menjadi suatu bentuk ibadah dan tanggung jawab dalam memenuhi kebutuhan keluarga. Menurut Najib 2013:148 berdasarkan ajaran agama Islam manusia tidak dihalangi untuk melakukan akumulasi kapital, dengan cara untuk memperolehnya diatur dalam Al-Quran dan Al-Hadis.

Ajaran agama tersebut menganjurkan kepada umat Islam agar memacu diri untuk bekerja keras dan berusaha semaksimal mungkin, dalam arti seorang muslim harus memiliki etos kerja tinggi, sehingga dapat meraih kesuksesan dan berhasil dalam menempuh kehidupan dunianya di samping kehidupan akheratnya (Saifullah, 2010:54). Salah satu ayat Al-Quran yang memerintahkan manusia untuk bekerja keras terdapat pada QS Al Insyiroh ayat 7-8. Masyarakat nelayan Desa Grajagan yang mayoritas beragama Islam secara tidak langsung memiliki spirit kerja keras, dimana spirit masuk pada diri manusia yang kemudian menjadi patokan manusia dalam bertindak.

Ajaran agama mengajarkan dan memerintahkan manusia untuk bekerja keras dan mempunyai etos kerja yang tinggi serta menjauhi sifat malas dan boros tetapi kenapa realitas pada masyarakat nelayan Desa Grajagan yang terjadi justru sebaliknya. Perumusan masalah yang akan diungkapkan dalam penelitian ini mengenai bagaimana spiritualitas agama dan etos kerja masyarakat dalam penanggulangan kemiskinan nelayan Desa 
Grajagan Kecamatan Purwoharjo Kabupaten Banyuwangi.

Berdasarkan pemaparan di atas, penelitian ini bertujuan untuk mengetahui bagaimana spiritualitas agama dan etos kerja masyarakat dalam penanggulangan kemiskinan nelayan Desa Grajagan Kecamatan Purwoharjo Kabupaten Banyuwangi.

\section{METODE}

Berdasarkan permasalahan dan tujuan penelitian, penelitian ini menggunakan metode penelitian deskriptif dengan pendekatan kualitatif. Penentuan lokasi penelitian menggunakan metode purposive area yaitu di Desa Grajagan Kecamatan Purwoharjo Kabupaten Banyuwangi. Subjek penelitian ini adalah masyarakat nelayan Desa Grajagan Kecamatan Purwoharjo Kabupaten Banyuwangi. Penentuan informan penelitian menggunakan metode snowball yaitu nelayan buruh dan nelayan tradisional sebanyak delapan informan inti dan empat informan tambahan. Metode pengumpulan data menggunakan metode: wawancara mendalam, observasi, dan dokumentasi. Analisis data menggunakan: reduksi data, penyajian data, dan kesimpulan atau verifikasi.

\section{HASIL DAN PEMBAHASAN \\ Hasil Penelitian \\ Kemiskinan Masyarakat Nelayan}

Profesi nelayan sebagai pemburu ikan di laut mengandung banyak tantangan, bahaya, berisiko tinggi dan pendapatan yang tidak dapat dipastikan. Pola pendapatan nelayan yang fluktuatif, tidak jelas, dan penuh risiko inilah yang menjadi penyebab kebiasaan hidup nelayan. Apabila pendapatan nelayan lumayan banyak biasanya nelayan membelanjakan pendapatannya cenderung boros hal tersebut dirasa lumrah karena tidak setiap hari pendapatan nelayan tinggi. Memasuki musim paceklik atau barat yang ditandai dengan ombak sangat besar nelayan akan memperoleh hasil tangkapan lebih sedikit yang berdampak pada turunnya pendapatan nelayan sehingga nelayan mengalami kekurangan. Untuk dapat memenuhi kebutuhan hidup, nelayan hutang kepada patronnya yaitu juragan darat dan dibayar pada saat pendapatan nelayan meningkat.

Masyarakat nelayan yang mempunyai keterampilan non fishing dapat bekerja diluar sektor perikanan seperti kuli bangunan dan tukang perahu. Sedangkan nelayan yang tidak punya keterampilan lain selama musim barat aktivitasnya hanya istirahat atau menganggur. Sebagian masyarakat nelayan tradisional maupun buruh tidak melakukan aktivitas pekerjaan lain untuk mengendalikan turunnya pendapatan dengan alasan tidak mempunyai keterampilan lain yang dapat dilakukan. Hal tersebut sejalan dengan penuturan nelayan selaku informan penelitian.

“... Istirahat mbak tidak mempunyai pekerjaan lainnya mbak, dikarenakan saya tidak mempunyai keterampilan lainnya bisanya cuman cari ikan tapi istri jualan untuk membantu (Hs, 58 tahun).

Pola hidup sebagian masyarakat nelayan yang malas cenderung tidak melakukan aktivitas pekerjaan lainnya pada saat musim barat, merupakan kebiasaan nelayan yang menjadikan masyarakat nelayan dalam lingkup kemiskinan kultural. Kemiskinan kultural pada masyarakat nelayan Desa Grajagan dilihat dari kebiasaan masyarakat nelayan yang enggan untuk bekerja keras dan menerima apa adanya. Sebagaimana yang dinyatakan oleh salah satu masyarakat nelayan selaku informan penelitian.

“... Menurut saya ya sudah bersyukur mbak, yang penting anak istri sehat masalah rezeki itu sudah ada takarannya sendiri berapapun hasilnya ya disyukuri aja mbak seumpama tidak bersyukur jadi kufur nanti diterima saja apa adanya mbak. Pendapatan saya segitu menurut saya sudah cukup ada yang lebih tidak punya kok mbak (R, 60 tahun).

Kemiskinan yang dialami masyarakat nelayan umumnya dilihat dari sudut pandang kultural. Nelayan dianggap miskin karena budaya mereka yang menyebabkan nelayan belum dapat keluar dari masalah kemiskinan. Mengukur tingkat kemalasan pada penelitian ini melihat dari segi bagaimana aktivitas masyarakat nelayan pada saat paceklik atau musim barat dan sepi ikan.

\section{Kehidupan Beragama Masyarakat Nelayan Desa Grajagan}

Setiap agama mengajarkan berbagai hal dalam menjalankan hidup yang menjadi pedoman dan panutan dalam menjalankan kehidupannya. Begitupun dengan agama Islam yang mengajarkan perihal bagaimana menjalani hidup di dunia dengan benar dan bermanfaat di akhirat nantinya. Ajaran Islam terkandung pada Al-Quran dan $\mathrm{Al}$ hadis yang menjadi pedoman umat Islam dalam hal beribadah dan menjalankan kehidupannya. Agama menjadi salah satu bentuk spirit/ide/gagasan bagi penganutnya yang kemudian menjadi patokan dalam bertindak. Salah satu ajaran agama Islam dalam mencari nafkah dan bekerja manusia harus bekerja keras, tidak malas, hidup sederhana, jujur dalam bekerja, dan bersyukur atas apa yang diperolehnya. Manusia yang memahami ajaran agama dengan baik dan benar maka akan menjalankan kehidupannya seperti bekerja, beribadah akan sesuai dengan apa 
yang diperintahkan dan apa yang diajarkan. Bagaimana manusia memahami ajaran agama dapat dilihat dari cara berperilaku dan bagaimana menjalani kehidupan sehari-harinya.

Masyarakat nelayan Desa Grajagan Kecamatan Purwoharjo Kabupaten Banyuwangi mayoritas beragama Islam. Dalam memahami ajaran agama Islam masyarakat nelayan Grajagan dirasa kurang baik, hal tersebut dilihat berdasarkan dalam pelaksanaan ritual yang dilaksanakan secara individu seperti sholat lima waktu, puasa, zakat, haji dan lainnya. Hal tersebut dikarenakan mereka kurang memahami apa yang telah diajarkan agamanya. Pada dasarnya mereka mengerti akan kebenaran agama yang dianutnya akan tetapi masyarakat kurang memahami ajaran agama Islam yang menjadi pedoman dan petunjuk bagi pemeluknya yang terkandung dalam Al-Quran dan hadis. Keadaan longgarnya pemahaman ajaran agama seperti inilah yang ada dalam diri masyarakat yang kemudian menjadi dasar bagaimana masyarakat menjalankan perintah agamanya.

Selain perilaku keagamaan tersebut dalam pelaksaaan ibadah lainnya seperti puasa juga belum diperhatikan oleh masyarakat. Dalam melaksanakan ibadah puasa masyarakat nelayan kurang memperhatikan bahwa agama Islam memerintahkan umatnya untuk berpuasa pada bulan ramadhan dan wajib hukumnya. Hal ini terlihat berdasarkan observasi peneliti yang melihat beberapa masyarakat yang minum kopi di warung, merokok, dan makan pada siang hari di bulan ramadhan.

Dalam perihal memahami perintah bekerja, masyarakat nelayan masih memahami bekerja hanya sebatas rutinitas yang harus dilakukan setiap harinya berulang-ulang untuk dapat memenuhi kebutuhan keluarganya. Seperti keterangan yang diberikan oleh informan sebagai berikut :

“... Bekerja itu menurut saya sekedar rutinitas, kalau ibadah itu lain ibadah itu seperti sholat, puasa, zakat dalam agama bekerja itu memang wajib untuk menafkahi keluarga" (Hs, 58 tahun).

Manusia yang memahami ajaran agama Islam akan memandang bekerja selain sebagai rutinitas dan kewajiban, bekerja merupakan suatu bentuk ibadah. Terkandung dalam Al Quran dan Hadis makna "bekerja" memperoleh nilai kedudukan yang tinggi, bahkan bekerja dipercaya sebagai bagian dari ibadah.

Masyarakat nelayan rata-rata mempercayai adanya kekuatan lain selain Allah, dengan artian masyarakat nelayan masih mencampurkan antara kepercayaan sebagai pemeluk agama Islam dengan tradisi yang berasal dari ajaran nenek moyang sebelum masuknya Islam. Dengan adanya tradisi dan kepercayaan yang dilakukan masyarakat nelayan dapat dikategorikan dalam varian masyarakat Islam abangan. Golongan masyarakat Islam abangan merupakan orang-orang yang memeluk agama Islam tetapi cara hidupnya masih banyak dipengaruhi oleh tradisi-tradisi Jawa sebelum masuknya Islam, yaitu tradisi yang menitikberatkan pada perpaduan unsur-unsur Islam, Hindu-Budha, dan animisme-dinamisme sebagai bentuk dari sinkritisme. Oleh karena itu rata-rata masyarakat nelayan mengembangkan tradisi yang bergantung kepada kekuatan lain yang dirasa mampu memberi jaminan dan keselamatan bagi nelayan.

\section{Etos Kerja}

Nilai dasar yang mendasari masyarakat nelayan Desa Grajagan untuk bekerja salah satunya berdasarkan nilai agama. Pada dasarnya agama merupakan suatu sistem nilai yang akan mempengaruhi atau menentukan pola hidup penganutnya. Jika individu bersungguh-sungguh dalam kehidupan agama, maka cara berpikir, bersikap, dan bertindak pasti diwarnai oleh ajaran agama yang dianutnya. Masyarakat nelayan yang memahami hakikat bekerja sebagai salah satu bentuk ibadah, amanah, rahmat yang harus dilakukan, nelayan akan mempunyai motivasi untuk bekerja keras karena bekerja dirasa sebagai suatu keharusan dan tanggung jawab untuk menafkahi dan memenuhi kebutuhan keluarga. Berbeda dengan masyarakat yang pada dasarnya mengetahui bahwa agama memerintahkan bekerja keras, bekerja sebagai bentuk ibadah tetapi dalam pelaksanaannya mereka tidak sesuai dengan apa yang diperintahkan. Perintah tersebut hanya sebagai pengetahuan saja sedangkan praktik kerjanya terpisah dari apa yang mereka ketahui.

Nilai agama yang dilakukan hanya sebatas simbol, sehingga menimbulkan ketidakseimbangan antara nafsu pemenuhan duniawi dengan praktik ajaran agama. Dengan demikian jika nelayan dihadapkan dengan keadaan yang memungkinkan tidak dapat bekerja seperti ketika musim paceklik atau barat mereka pasrah tanpa melakukan aktivitas lain. Masyarakat yang memahami bekerja hanya sebagai suatu rutinitas belum menunjukkan motivasi untuk bekerja keras karena nelayan akan bekerja sesukanya. Seperti yang dikatakan oleh beberapa informan informan penelitian :

“... Menurut saya ya mbak, bekeja itu rutinitas semata kalau ibadah itu lain ibadah ya seperti sholat, puasa, ngaji tetapi menurut agama bekerja itu wajib" (H, 58 tahun).

Berdasarkan penuturan beberapa informan tersebut dapat dilihat bahwa nilai agama hanya sebatas ibadah belum menjadi spirit bagi masyarakat nelayan yang dapat menjadi salah satu faktor masyarakat nelayan kurang bekerja keras. Motivasi bekerja masyarakat nelayan Grajagan bersumber dari keyakinan individu bahwa bekerja merupakan ibadah. Bekerja keras merupakan suatu hal yang harus dilakukan untuk dapat melangsungkan hidup. Untuk dapat memenuhi kebutuhan anggota keluarga mulai dari kebutuhan pangan sehari-hari, sandang yang 
digunakan, dan kebutuhan pendidikan bagi anak mengharuskan nelayan harus bekerja keras.

Selain faktor agama etos kerja nelayan Grajagan juga dipengaruhi oleh faktor nilai-nilai budaya yang tumbuh pada masyarakat. Masyarakat yang memiliki sistem nilai budaya yang maju akan memiliki etos kerja yang tinggi, sebaliknya masyarakat yang memiliki sistem nilai budaya yang konservatif akan memiliki etos kerja yang rendah. Budaya nelayan yang menganggur pada musim paceklik, bersikap konsumtif sudah tumbuh dalam masyarakat yang menjadi suatu kebiasaan.

\section{Modal Sosial sebagai Strategi Penanggulangan Kemiskinan}

Modal sosial melibatkan interaksi sosial di antara individu, interaksi sosial tersebut berperan penting karena membantu individu, komunitas, dan masyarakat untuk mencapai tujuan bersama. Penanggulangan kemiskinan masyarakat nelayan dimulai pada tingkat mikro yaitu, individu rumah tangga. Dalam hal ini, diramalkan bahwa potensi untuk mendorong akumulasi modal sosial di kalangan rumah tangga miskin nelayan sebagai salah satu strategi yang mungkin untuk menanggulangi kemiskinan nelayan. Gagasan utama dari kerangka kerja pendekatan jaringan adalah bahwa jejaring sosial adalah aset berharga yang menghasilkan aliran pendapatan bagi rumah tangga. Modal sosial dibangun selama interaksi, yang terjadi karena alasan sosial, budaya, atau agama. Ini memungkinkan orang membangun komunitas, berkomitmen satu sama lain, dan merajut tatanan sosial. Bukti kualitatif yang terjadi pada masyarakat nelayan Grajagan dengan gerakan "Asosiasi Komunitas Nelayan", serta "Yasinan" menunjukkan bahwa peran modal sosial menjadi penting. Secara sederhana modal sosial dapat ditunjukkan oleh komponen-komponen penting yang menyertainya, yaitu kepercayaan (trust), keyakinan (belief), norma-norma (norms), saling memberi (reciprocity), aturan-aturan (rules) dan jaringan-jaringan (networks).

\section{Pembahasan}

Mayoritas masyarakat nelayan Desa Grajagan Kecamatan Purwoharjo Kabupaten Banyuwangi memeluk agama Islam. Tradisi Islam pada dasarnya tidak membatasi dalam proses akumulasi kapital tetapi cara memperolehnya sesuai dengan etika yang diatur dalam al-Quran dan Hadis. Sebagai pemeluk agama Islam disamping mempercayai Allah Subhanawataala sebagai Tuhannya dan bergantung kepada-Nya masyarakat nelayan juga mempercayai adanya kekuatan lain diluar nalar manusia yang dijadikan sebagai sandaran yang kemudian mempengaruhi cara hidup dan pandangan masyarakat nelayan.

Spiritualitas yang berakar dari nilai agama belum mampu menumbuhkan spirit sebagai penggerak ekonomi masyarakat Desa Grajagan. Hal tersebut dikarenakan longgarnya pemahaman ajaran agama nelayan serta ritual yang dilakukannnya seperti sholat, puasa, selametan, dan sebagainya hanya sebagai ritual dan adat istiadat semata, tanpa dipahami bagaimana makna subtansialnya. Oleh karena itu, masyarakat Grajagan termasuk dalam kategori manusia dengan karakter culture dogmatic. Seperti yang dikemukakan Nelson, 2009 dalam Syamsuddin, 2012:115 bahwa Cultural Dogmatic, ditandai dengan tingginya religi dan rendah spiritual, orang ini adalah orang yang taat melakukan ibadah ritual tetapi rendah dalam pemaknaan akan nilai-nilai terdalam dari falsafah makna kehidupan dan transendensi.

Sebagian masyarakat nelayan Desa Grajagan dirasa masih fatalistik dan sikap pasrah nrimo ing pandum yang tinggi yang menyebabkan sikap kurang bekerja keras dan kepasrahan dalam mencari rezeki. Fatalistik merupakan suatu pemahaman bahwa segala kejadian alam dan hidup manusia berada diluar kuasa manusia untuk merubahnya. Etos kerja muncul karena adanya dorongan dari diri manusia serta terbentuk melalui pemahaman terhadap ajaran agama.

Dengan adanya sikap kepasrahan yang tinggi berdampak pada perilaku masyarakat nelayan yang cenderung malas pada saat musim paceklik tiba karena beranggapan bahwa rezeki itu sudah ada porsinya sendiri. Untuk membuat sebuah pekerjaan itu berhasil, yang paling penting adalah sikap terhadap pekerjaan itu. Etos kerja muncul dari dorongan batin manusia serta terbentuk melalui pemahaman terhadap ajaran agama. Seperti berdasarkan etika Protestan, mereka bekerja keras dan tekun bukanlah karena mereka digaji besar akan tetapi ketekunan dan kerja keras sebagai bagian dari tuntutan agama (Weber, 2006:143).

Masyarakat nelayan Desa Grajagan sangat kental dengan ritual selametan nya. Ritual selametan merupakan ciri khas yang paling kentara dari masyarakat abangan. Seperti pendapat Geertz yang menurutnya selametan merupakan upacara dasar yang inti dimana dunia abangan paling menonjol (Geertz, 1983:17). Tergolong dalam varian Islam abangan, masyarakat nelayan dalam memahami ajaran Islam dirasa kurang serta longgar dalam menjalankan syariat agama. Longgarnya pemahaman dan praktik menjalankan syariat Islam dapat dilihat dari berbagai aktivitas dan tingkah laku keseharian masyarakat nelayan. etika kerja yang dipahami tidak sesuai dengan ajaran Islam.

Pada penelitian ini diketahui bahwa nelayan termasuk struktur sosial Islam abangan yang spiritualitas agamanya belum mampu mendorong perekonomian masyarakat dikarenakan kualitas keagamaannya lebih rendah 
dibangingkan santri dan priyayi. Sikap konsumtif masyarakat nelayan ketika memperoleh penghasilan yang cukup banyak timbul karena nelayan mengalami masa kekurangan yang panjang. Seperti yang dikatakan oleh Kusnadi (2002:15) yang menyatakan bahwa gaya hidup konsumtif masyarakat nelayan merupakan kompensasi psikologis dari kesengsaraan hidup yang cukup lama atau upaya untuk menyenangkan diri sendiri dalam sesaat dan menikmati kehidupan yang selayaknya.

\section{PENUTUP}

Agama Islam mengajarkan etika kerja keras, tetapi realita yang terjadi pada masyarakat nelayan justru kemiskinan. Kemiskinan yang dialami masyarakat nelayan Grajagan disebabkan oleh faktor kultural lingkungan sosial budayanya. Kultural masyarakat nelayan Desa Grajagan memiliki tingkat kepasrahan nrimo ing pandum yang tinggi, serta fatalistik dalam menjalani hidup. Meskipun nelayan hidup dalam kekurangan tetapi mereka tidak merasa kekurangan karena mereka sudah terbiasa.

Mayoritas masyarakat nelayan Grajagan beragama Islam tetapi dalam memahami ajaran agama Islam, nelayan dirasa sangat longgar. Nelayan belum mangaplikasikan ajaran agama dalam kehidupannya dengan baik. Masyarakat nelayan tergolong masyarakat Islam abangan, ciri yang paling menonjol dari masyarakat abangan adalah ritual selametan, ritual selametan yang sifatnya individu maupun kolektif pada dasarkan dilakukan sebagai sandaran dalam mencari keselamatan dalam bekerja, dan supaya tidak dibedakan dalam kelompoknya. Tetapi masyarakat nelayan dalam melaksanakan ritual hanya sebatas ritual adat dan kebiasaan tanpa memahami makna subtansi dilakukannya ritual tersebut.

Peranan Islam sebagai norma etika ternyata belum mampu mendorong etika kerja masyarakat nelayan untuk membangun perilaku kerja keras, hemat, disiplin, serta menjauhi perilaku konsumtif. Hal tersebut dikarenakan ritual yang dilaksanakan baik yang individu maupun kolektif belum mampu menumbuhkan spirit yang mendorong etos kerja nelayan. Ritual hanya dilaksanakan sebagai tradisi menggugurkan kewajiban saja tanpa dipahami makna subtansialnya. Nilai ajaran agama hanya sebagai ibadah saja belum dipahami sebagai spirit yang kemudian menjadi patokan dalam bertindak.

Berdasarkan kesimpulan diatas, maka penulis memberikan saran kepada semua pihak-pihak terkait:

1. Sebagai sebuah negara dengan wilayah laut yang luas, pemerintah diharapkan lebih memiliki perhatian dan keperdulian seperti memberikan wawasan pengetahuan mengenai kegiatan perikanan, buruh nelayan maupun nelayan tradisional perlu adanya tambahan wawasan mengenai kewirausahaan di luar sektor perikanan sehingga di saat-saat tidak melaut mereka memanfaatkan waktu luang untuk melakukan aktivitas lain yang dapat menambah aktivitas lain yang dapat menambah pendapatan.

2. Diperlukan peningkatan nilai pemahaman keagamaan serta penguatan lembaga-lembaga sosial ekonomi di masyarakat. Salah satu yang dapat dilakukan adalah dengan penumbuhan karakter dalam keluarga. 


\section{DAFTAR PUSTAKA}

\section{Buku}

Abdullah, Taufik (ed.). 1979. Agama, Etos Kerja dan Perkembangan Ekonomi. Jakarta: LP3ES bekerjasama dengan YOI dan Leknas-LIPI. Cetakan Pertama.

Anoraga, P. 2009. Managemen Bisnis. Jakarta: Rineka Cipta

Gunnard Myrdal. 1970. An Approach to the Asian Drama. New York: Vintage Books.

Harefa, A. 2004. Membangkitkan Etos Kerja Profesionalisme. Jakarta: Gramedia

Ismail, Arifuddin. 2012. Agama Nelayan. Yogyakarta: Pustaka Pelajar

Idrus, M. 2009. Metode Penelitian Ilmu Sosial. Jakarta : Erlangga.

Kusnadi. 2015. Pembangunan Wilayah Pesisir Terpadu. Yogyakarta : Graha Ilmu.

Kusnadi, 2007. Jaminan Sosial Nelayan. Yogyakarta : PT. LkiS Pelangi Aksara Yogyakarta.

Lorens, Bagus. 2000. Kamus Filsafat Cetakan Kedua. Jakarta: Gramedia

Mulyadi, S. 2005. Ekonomi Kelautan. Jakarta: PT. Raja Grafindo Persada.

Maipita, I. 2014. Mengukur Kemiskinan dan Distribusi Pendapatan. Yogyakarta: UPP STIM YKPN.

Nelson, J.M. (2009) Psychology, Religion and Spirituality. New York: Springer Science Business Media

Rustanto, B. (2015). Menangani Kemiskinan. Bandung: PT Remaja Rosdakarya

Suyanto, B. 2013. Anatomi Kemiskinan. Malang: In-Trans Publishing

Sugiyono. 2017. Metode Penelitian Kuantitatif, Kualitatif, dan R\&D. Bandung: Alfabeta

Sinamo, Jansen. 2005. 8 Etos Kerja Profesional. Jakarta: Intitut Darma Mahardika.

Tasmara, T. 2002. Membudayakan Etos Kerja Islami. Jakarta: Gema Insani Press

Weber, Max. 2006. Etika Protestan dan Spirit Kapitalisme (terjemahan). Yogyakarta: Pustaka Pelajar

\section{Jurnal}

Alim, M.K. 2012. Etos Kerja Masyarakat Nelayan (Studi di Desa Kaliuntu Kecamatan Jenu Kabupaten Tuban Jawa Timur). Skripsi. Yogyakarta. Fakultas Ilmu Sosial dan Humaniora. UIN Sunan Kalijaga.

Birsyada, I. 2017. The Business Ethics of Royal Family: Mangkunegara IV, Sufism and Economy in Java. International Journal of Applied Business and Economic Research. ISSN:0972-302.vol.15.no.7.2017.

Hamdani Thaha dan Muh Ilyas. 2016. Perilaku Beragama dan Etos kerja Masyarakat Pesisir di kelurahan Penggoli kecamatan Wara Utara kota Palopo. PALITA: Journal of Social-Religi Research April 2016, Vol.1, No.1, hal.1-16 ISSN(P): 2527-3744; ISSN(E):2527-3752

Marzali, Amri. 2016. Agama dan Kebudayaan. UMBARA : Indonesian Journal of Anthropology.

Nadjib, Mochammad. (2013). Agama, Etika, dan Etos Kerja dalam Aktivitas Ekonomi Masyarakat Nelayan Jawa. Jakarta: Puslitbang Ekonomi dan Pembangunan LIPI. Volume 21. No.2. Tahun:2013 
Rokhimah. 2017. Etos Kerja Masyarakat Nelayan Perspektif Ekonomi Islam (Studi Kasus di Desa Jetis Kecamatan Nusawungu Kabupaten Cilacap). Skripsi. Purwokerto. Fakultas Ekonomi dan Bisnis Islam IAIN Purwokerto

Sadly, E. 2017. Working ethos on fisherman society in Bagan Kuala village Tanjung Beringin sub-District Serdang Bedagai regency. IOSR Journal of Business and Management (IOSRJBM), vol. 19, no. 8, 2017, pp. 85-92.

Steffy, K. (2013). Religious Orthodoxy and the American Worker. Sociology of Religion. 74:1 1-29doi:10.1093/ socrel/srs074 Advance Access Publication 9 January 2013

Saifullah. 2010. Etos Kerja dalam Perspektif Islam. Jurnal Sosial Humaniorah, Vol 3 No.1. Juni 2010

Saputro, dkk. 2016. Neo-Petik Laut: Local Wisdom In Environmental Conservation And Improvement Of Coastal Community Economic Blue Spring Malang. ECSOFiM: Economic and Social of Fisheries and Marine Journal. 2016. 04(01): 28-35

Syamsuddin. 2012. Memahami Dimensi Spiritualitas dalam Praktik Pekerjaan Sosial. Penang Malaysia: Universiti Sains Malaysia. Volume 17. No.2. Tahun: 2012

Widodo, S. 2011. Strategi Nafkah Berkelanjutan Bagi Rumah Tangga Miskin di Daerah Pesisir. Makara, Sosial Humaniora. Vol. 15

\section{Peraturan Pemerintah}

Peraturan Presiden Republik Indonesia Nomor 166 Tahun 2014. Program Percepatan Penanggulangan Kemiskinan. 03 November 2014. Jakarta

\section{Artikel dari Internet}

Badan Pusat Statistik. 2018. Persentase Penduduk Miskin September 2017, (https://www.bps.go.id diakses tanggal 13/02/2018) 